\title{
Site Selection for Bud and Germ Tube Emergence in Candida albicans
}

\author{
By W. LAJEAN CHAFFIN \\ Department of Microbiology, Texas Tech University Health Sciences Center, Lubbock, \\ Texas 79430, USA
}

(Received 19 July 1983; revised 20 September 1983)

The site selection for bud and germ tube emergence has been studied in the dimorphic yeast Candida albicans. The fluorescent dye Calcofluor was used to stain bud scars. Two different modes of site selection were observed in yeasts. On cells cultivated at $23-28{ }^{\circ} \mathrm{C}$, buds emerged primarily at one end of the cell at adjacent sites suggesting a type of persistent memory. Sites selected on yeasts growing at $37^{\circ} \mathrm{C}$ were non-adjacent and scattered over the cell. The pattern of bud emergence during resumption of budding from stationary phase, or after temperature shift between conditions, was not a simple transition between modes. During these transitions the budding pattern sequentially passed through non-adjacent and adjacent budding modes before establishing the pattern characteristic of the growth temperature. Germ tubes emerged in a non-adjacent pattern from cells grown to stationary phase at $28^{\circ} \mathrm{C}$. The higher frequency of nonadjacent emergence and the absence of sequential pattern changing in site selection for germ tubes suggested that non-adjacent site selection for germ tubes and buds might not be the same.

\section{INTRODUCTION}

Cells of Candida albicans are able to grow either as budding yeasts or hyphae. As a structure involved in the maintenance of these morphological forms, the cell wall has been the focus of many investigations. Biosynthesis of cell wall components and/or precursors and inter- and intramolecular relationships of components have been suggested as possible sites of morphogenetic regulation in C. albicans (Nickerson, 1963; Chattaway et al., 1973). Hyphal, spherical and ellipsoidal growth forms result from a polarized extension (apical growth), uniform extension (spherical) or combination of the two (ellipsoidal growth) (see Discussion in Farkaš, 1979).

During cellular morphogenesis, the regulation of the mode of growth is preceded by a selection of the site at which growth will be initiated. In this report, the site selection for bud emergence has been examined in yeasts grown at two different temperatures and for germ tube emergence. These studies utilized fluorescent microscopy of cells stained with Calcofluor, a dye with an affinity for $\beta$-linked hexopyranose polymers (Maeda \& Ishida, 1967). The results suggested that site selection is primarily temperature sensitive and may differ for yeast bud and germ tube formation.

\section{METHODS}

Organism and culture conditions. Candida albicans B311 (Hasenclever) was maintained on yeast extract-peptoneglucose (YEPG) agar plates. Cultures were grown in the defined minimal medium supplemented with amino acids described by Lee et al. (1975). All cultures were grown in a gyratory incubator shaker at $180-200$ r.p.m. at $28^{\circ} \mathrm{C}$ or $37^{\circ} \mathrm{C}$. For yeast growth at $37^{\circ} \mathrm{C}$, the $\mathrm{pH}$ of the medium was adjusted from 7.4 to 4.5 (Mitchell \& Soll, 1979a). For growth resumption experiments, stationary phase yeast cells grown in liquid medium were centrifuged and

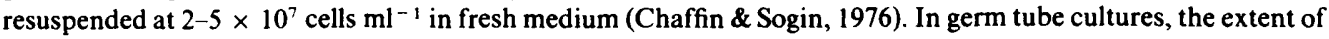
morphological conversion was monitored by microscopy as previously described (Chaffin \& Sogin, 1976), except that cells were suspended in fluorescent dye. Exponential cultures were obtained by diluting an exponential culture

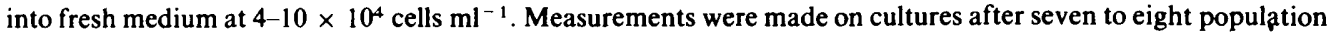
doublings and at least two population doublings before stationary phase. 
Fluorescent microscopy and time-lapse photomicroscopy. For fluorescent microscopy, cells were collected from culture by centrifugation and were resuspended in $0.1 \%(\mathrm{v} / \mathrm{v})$ Calcofluor ST (gift from American Cyanamid Co., Wayne, N. J., USA) or primulin $\left(0.1 \mathrm{mg} \mathrm{ml}^{-1}\right)$ (Cassone et al., 1973). Cells were viewed with a Zeiss Standard RA microscope equipped for fluorescence. Exciter filters BG38, BG12 and UG1 and barrier filter insert 47 were used. Cells in each field examined were counted for age and/or location of buds or germ tube with respect to bud scars. Many fields were examined for each determination. Photographs were taken using Kodak Tri-X film and a $35 \mathrm{~mm}$ camera attachment. Latex beads of known diameter (Sigma) were also photographed and all pictures and prints made at the same magnification.

For time-lapse photomicroscopy, cells were grown at $23^{\circ} \mathrm{C}$ on YEPG plates. Cells from the plate were resuspended in sterile $0.9 \%(\mathrm{w} / \mathrm{v}) \mathrm{NaCl}$ and allowed to settle on the surface of agar on a microscope slide (Hartwell \& Unger, 1977). Photographs were taken using Kodak Tri-X film and a Zeiss Standard RA microscope equipped with a $35 \mathrm{~mm}$ camera.

Statistical analyses. Comparison of site selection between different conditions utilized Student's $t$ distribution and Duncan's multiple range test. The Chi-square $\left(\chi^{2}\right)$ test was used with some observations. In all cases values from standard statistical tables used $P=0.05$.

\section{RESULTS}

\section{Localization of site of bud emergence by time-lapse photomicroscopy}

Time-lapse photomicroscopy was utilized to observe the site of bud emergence through several cell division cycles of cells growing at $23^{\circ} \mathrm{C}$ on solid medium. Of the 52 buds observed, $90 \%$ emerged at the same end of the cell as the previous bud. Eight of the cells observed were followed for four or more cell division cycles. The position of emergence of the first bud on daughter cells with respect to the birth pole was observed. For the majority of daughters (30 of 42), the end at which the first bud emerged and the birth end were the same. These observations were consistent with an ellipsoidal yeast with multipolar budding, i.e. each bud emerges at a different site on the mother cell surface (Beran, 1968).

\section{Fluorescent staining patterns}

Two fluorescent dyes, primulin and Calcofluor, have been used to stain reproductive scars in yeast (Beran, 1968; Hayashibe \& Katohda, 1973; Sloat et al., 1981). Both dyes produce fluorescent cells in C. albicans (Cassone et al., 1973; Mitchell \& Soll, 1979b; Soll \& Mitchell, 1983; W. L. Chaffin, unpublished results). Using Calcofluor, Soll and co-workers (Mitchell \& Soll, $1979 b$; Soll \& Mitchell, 1983) report a lightly staining septal region at the mother cell-bud junction early in bud emergence which subsequently converts to a brightly staining septum. Cells grown in defined liquid medium were stained with each dye. On many cells, small rings were observed adjacent to a bud (Fig. $1 a, b$ ). For a few parent/daughter combinations in which the daughter remained with the larger parent cell, a ring was observed on the parent just below the bud. These small rings were located in positions consistent with the site of bud scars predicted from the time lapse photomicroscopy and consistent with observations of Saccharomyces cerevisiae, the most studied multipolar budding yeast (Beran, 1968). Calcofluor, which appeared to give a more intense fluorescence and less diffuse image, was used in all subsequent experiments.

\section{Bud scar distribution on growing and stationary phase yeasts}

The proportion of cells in growing and stationary phase cultures exhibiting a budding history at one or both ends was determined. In stationary phase cultures grown at $28{ }^{\circ} \mathrm{C}, 85 \%$ of the cells with two or more bud scars were observed to have those scars at the same end (Table 1). Similarly, in exponential cultures, $94 \%$ of the cells with evidence of two or more budding cycles were observed to have all budding events at the same end (Table 1). There was no significant difference between the proportion of cells with scars located at one end in exponential and stationary phase cultures. The frequency of cells with scars clustered at one end was somewhat reduced in cultures grown at $28^{\circ} \mathrm{C}$ with an initial medium pH of $4 \cdot 5$. Bud scars clustered at one end of the cell are shown in Fig. $1(a, b, g)$. 

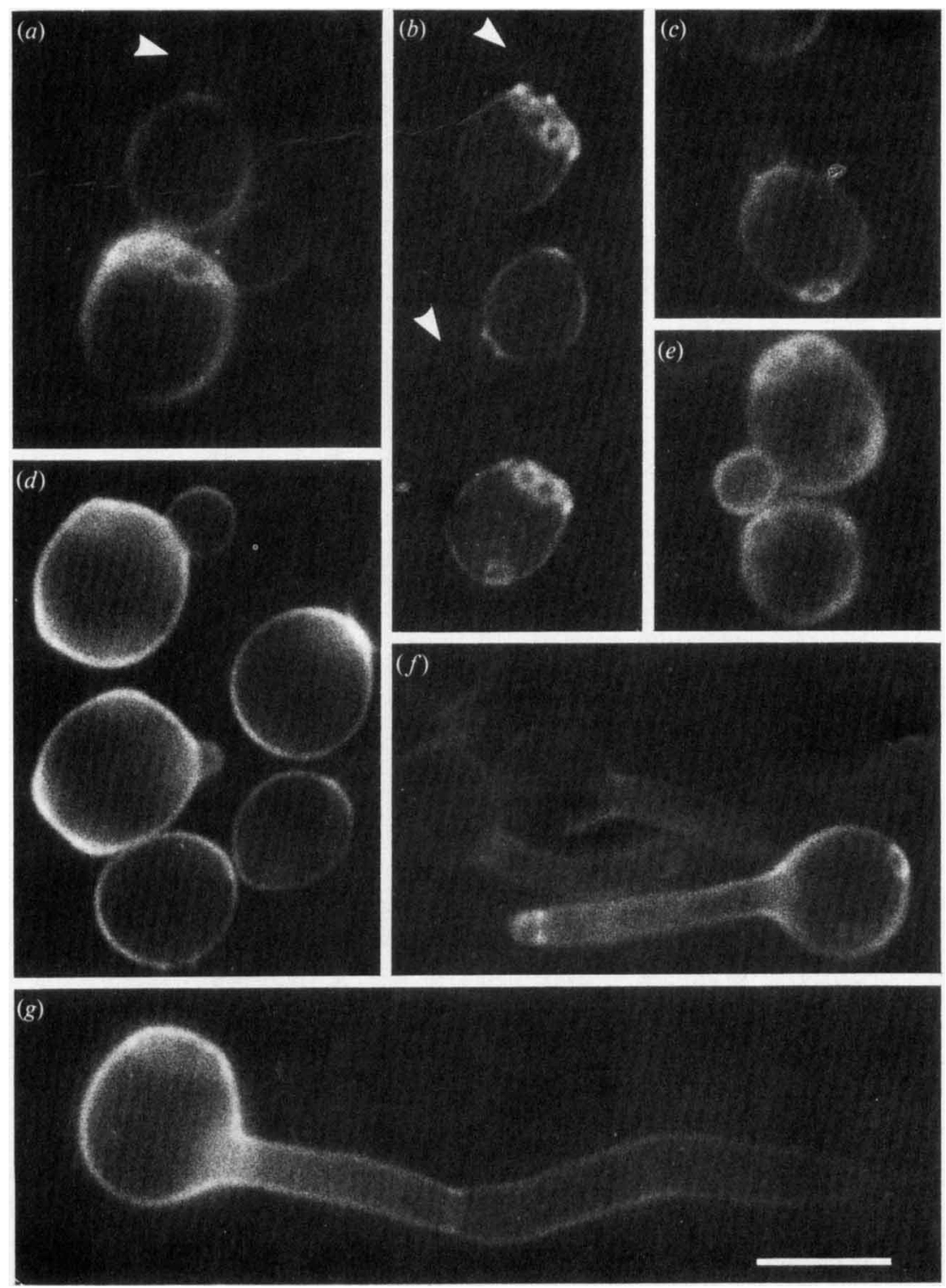

Fig. 1. Fluorescent photomicrographs showing the pattern of site selection for yeasts growing at different temperatures and germ tubes. Cells were stained with Calcofluor and photographed as described in Methods. $(a, b)$ Yeasts were cultivated at $28^{\circ} \mathrm{C}$. Bud scars were located primarily at one end of the cell and new buds emerged adjacent to previous scars. Some multiply scarred cells showed scars at both ends $(b) .(c-e)$ Yeasts were grown at $37^{\circ} \mathrm{C}$. Many of the second buds were initiated away from the site of the first bud $(c)$. Multiply scarred cells showed a scattered pattern of site selection $(d)$ as well as both adjacent and scattered scars $(e) .(f, g)$ Yeasts were grown to stationary phase at $28^{\circ} \mathrm{C}$ and resuspended in fresh medium at $37^{\circ} \mathrm{C}$ as described in Methods. Germ tubes emerged in positions opposite $(f)$ and lateral $(g)$ to bud scars from yeast growth. Arrows show the location of poorly fluorescent buds $(a, b)$. The bar marker represents $2 \mu \mathrm{m}$. 
Table 1. Distribution of bud scars on growing and non-growing yeasts

Cells were grown in defined liquid medium and stained with Calcofluor white as described in Methods. Observations from independent cultures were averaged.

\begin{tabular}{|c|c|c|c|c|c|c|}
\hline \multirow[b]{2}{*}{$\begin{array}{l}\text { Temperature } \\
\left({ }^{\circ} \mathrm{C}\right)\end{array}$} & \multirow[b]{2}{*}{$\begin{array}{l}\text { Growth } \\
\text { state }\end{array}$} & \multirow[b]{2}{*}{ pH } & \multirow[b]{2}{*}{$\begin{array}{l}\text { Cells } \\
\text { counted }\end{array}$} & \multirow[b]{2}{*}{$\begin{array}{l}\text { Cells with } \geqslant 2 \\
\text { division cycles* }\end{array}$} & \multicolumn{2}{|c|}{$\begin{array}{c}\text { Average scar distribution } \\
\text { ( } \% \text { cells) }\end{array}$} \\
\hline & & & & & Adjacent & Non-adjacent \\
\hline 28 & Exponential & $7 \cdot 4$ & $\begin{array}{l}327 \dagger \\
151 \dagger \\
283 t\end{array}$ & $\begin{array}{l}327 \\
151 \\
103\end{array}$ & $94 \pm 4$ & $6 \pm 4$ \\
\hline 28 & Stationary & $7 \cdot 4$ & $\begin{array}{l}361 t \\
324 t \\
121 t\end{array}$ & $\begin{array}{r}84 \\
90 \\
121\end{array}$ & $85 \pm 4$ & $15 \pm 4$ \\
\hline 28 & Stationary & $4 \cdot 5$ & $\begin{array}{l}447 \ddagger \\
326 \ddagger \\
469 \ddagger \\
477 \ddagger\end{array}$ & $\begin{array}{r}102 \\
95 \\
105 \\
121\end{array}$ & $74 \pm 6$ & $26 \pm 6$ \\
\hline 37 & Exponential & $4 \cdot 5$ & $\begin{array}{l}266 \ddagger \\
291 \ddagger \\
307 \ddagger\end{array}$ & $\begin{array}{r}96 \\
108 \\
109\end{array}$ & $17 \pm 5$ & $83 \pm 5$ \\
\hline 37 & Stationary & $4 \cdot 5$ & $\begin{array}{l}256 t \\
254 t \\
247 t\end{array}$ & $\begin{array}{l}57 \\
36 \\
42\end{array}$ & $16 \pm 2$ & $84 \pm 2$ \\
\hline
\end{tabular}

* For cultures in the exponential growth phase, the position of the bud on budded cells was included in the budding history.

+ Only cells with $\geqslant 2$ cell division cycles were tabulated.

$\ddagger$ All cells were counted.

Very different bud scar patterns were observed among cells from exponentially growing and stationary phase cultures incubated at $37^{\circ} \mathrm{C}$. Only $17 \%$ of the exponential population and $16 \%$ of the stationary phase population with evidence of two or more budding cycles showed scars clustered at one end (Table 1). The majority of cells which had initiated at least two cycles had bud scars which were not clustered. There was no significant difference between the proportion of cells with non-adjacent bud scars when exponential and stationary phase cultures were compared. However, there was a significant difference when bud scar patterns from cells grown at $28^{\circ} \mathrm{C}$ were compared to yeast cells grown at $37^{\circ} \mathrm{C}$.

Parental cells that have completed one budding cycle are present in greater numbers than cells with multiple bud scars (W. L. Chaffin, unpublished results). This frequency coupled with the high proportion of cells with non-adjacent scars suggested that at $37^{\circ} \mathrm{C}$ many cells must initiate their second bud at a site away from the first bud. A cell with a second bud initiated at the opposite end from the first bud is shown in Fig. $1(\mathrm{c})$. The location of scars on older parents grown at $37^{\circ} \mathrm{C}$ suggested a less ordered budding site sequence than that observed at lower temperatures. Rather than being distributed in clusters at one end or both ends of the cell, bud scars on cells grown at $37^{\circ} \mathrm{C}$ appeared to be scattered over the surface (Fig. $1 d$ ). Some cells with multiple bud scars showed both adjacent and scattered scars (Fig. $1 e$ ).

\section{Bud scar distribution of yeasts having bipolar scar pattern}

Cells on which scars were not clustered at one end were further characterized in stationary phase populations grown at $28^{\circ} \mathrm{C}$ (Table 2). These cells had scars located at both ends. Cells with two or more scars comprised about $20 \%$ of the population, but only about one-tenth of this group had scars at both ends. If two or more scars were located at the same end, the scars were clustered or appeared adjacent. Scars on both ends were more frequently observed on parent cells which had completed at least three cell division cycles. 
Table 2. Characteristics of cells with non-adjacent bud scars

Cells were grown at $28^{\circ} \mathrm{C}$ in liquid defined medium to stationary phase and stained with Calcofluor as described in Methods. All cells with a non-adjacent pattern of bud scars in each microscopic field examined were tabulated.

\section{Parameter}

Number of cells observed

Percentage cells with one scar at opposite end

Average age of cells with one scar at opposite end

Average age of cells with two or more scars at each end

Range of scars per cell
Measurement

44

88

3.4

$5 \cdot 2$

$2-6^{*}$

* Cells with more than six scars were observed in the population, but were not in the fields tabulated for this sample.

\section{Table 3. Distribution of bud and germ tube sites during outgrowth of stationary phase yeasts}

Cells were grown to stationary phase in liquid defined media at $28^{\circ} \mathrm{C}, \mathrm{pH} 7 \cdot 4$, or $37^{\circ} \mathrm{C}, \mathrm{pH} 4 \cdot 5$. Cells were then inoculated into fresh medium under various conditions to resume growth either as budding yeasts or germ tubes. After 180-205 min of outgrowth, cells were stained with Calcofluor and the location of emerging buds or germ tubes was determined as described in Methods. Observations from independent cultures were averaged.

\begin{tabular}{|c|c|c|c|c|c|c|c|}
\hline \multirow{2}{*}{$\begin{array}{l}\text { Temperature } \\
\text { for outgrowth } \\
\left({ }^{\circ} \mathrm{C}\right)\end{array}$} & \multirow[b]{2}{*}{$\mathrm{pH}$} & \multirow{2}{*}{$\begin{array}{l}\text { Growth } \\
\text { state }\end{array}$} & \multirow{2}{*}{$\begin{array}{l}\text { Temperature } \\
\text { of growth to } \\
\text { stationary } \\
\text { phase } \\
\left({ }^{\circ} \mathrm{C}\right)\end{array}$} & \multirow{2}{*}{$\begin{array}{c}\text { Cells } \\
\text { counted }\end{array}$} & \multirow{2}{*}{$\begin{array}{c}\text { Cells } \\
\text { with } \geqslant 2 \\
\text { division } \\
\text { cycles }\end{array}$} & \multicolumn{2}{|c|}{$\begin{array}{c}\text { Average } \\
\text { site distribution } \\
(\% \text { cells })\end{array}$} \\
\hline & & & & & & Adjacent & Non-adjacent \\
\hline 37 & $7 \cdot 4$ & $\begin{array}{l}\text { Germ tube } \\
\text { formation }\end{array}$ & 28 & $\begin{array}{r}244^{*} \\
224^{*} \\
250^{*} \\
67+\end{array}$ & $\begin{array}{r}108 \\
69 \\
81 \\
26\end{array}$ & $4 \pm 1 \S$ & $96 \pm 1$ \\
\hline 28 & $7 \cdot 4$ & $\begin{array}{l}\text { Resumption } \\
\text { of budding }\end{array}$ & 28 & $\begin{array}{r}122 \ddagger \\
76 \ddagger \\
243 \ddagger\end{array}$ & $\begin{array}{r}59 \\
47 \\
115\end{array}$ & $59 \pm 41$ & $41 \pm 4$ \\
\hline 28 & $7 \cdot 4$ & $\begin{array}{l}\text { Resumption } \\
\text { of budding }\end{array}$ & 37 & $\begin{array}{r}156 \ddagger \\
70 \ddagger \\
150 \ddagger\end{array}$ & $\begin{array}{l}69 \\
30 \\
47\end{array}$ & $42 \pm 191$ & $58 \pm 19$ \\
\hline 37 & $4 \cdot 5$ & $\begin{array}{r}\text { Resumption } \\
\text { of budding }\end{array}$ & 28 & $\begin{array}{l}289 \ddagger \\
219 \ddagger \\
238 \ddagger\end{array}$ & $\begin{array}{r}136 \\
95 \\
95\end{array}$ & $48 \pm 101$ & $52 \pm 10$ \\
\hline 37 & $4 \cdot 5$ & $\begin{array}{r}\text { Resumption } \\
\text { of budding }\end{array}$ & 37 & $\begin{array}{l}207 \ddagger \\
182 \ddagger \\
514^{*}\end{array}$ & $\begin{array}{l}69 \\
55 \\
38\end{array}$ & $35 \pm 41$ & $65 \pm 4$ \\
\hline
\end{tabular}

- All cells were counted.

† Only cells with germ tubes were counted.

‡ Only cells with buds less than one half the diameter of the parent cell were counted.

$\S$ On cells with more than one germ tube, the position of the longer was tabulated.

I The location of the emerging bud was tabulated as adjacent or non-adjacent to a previous scar irrespective of the scar distribution of the cell.

\section{Bud and germ tube site selection during outgrowth of stationary phase of yeasts}

Based on the previous observations, two simple patterns for site selection during the resumption of budding growth were considered. If the site selection mechanism did not remain operative during stationary phase, or was rapidly inactivated by growth conditions, then the budding pattern should be characteristic of the conditions of growth resumption. On the other hand, if the mechanism for site selection remained operative during stationary phase and was not rapidly inactivated by different conditions, then the budding pattern should show a transition between the pattern associated with the growth conditions of the stationary phase cells and with the conditions for resuming growth. The former possibility was examined first (Table 3). When yeasts grown to stationary phase at $28^{\circ} \mathrm{C}$ resumed growth at the same 


\section{Table 4. Bud site selection during resumption of yeast growth}

Yeasts cells were grown to stationary phase in liquid defined medium at $28^{\circ} \mathrm{C}$, pH 7.4, or $37^{\circ} \mathrm{C}, \mathrm{pH} 4.5$. Cells were inoculated into fresh medium at either temperature and stained with Calcofluor at intervals following reinitiation of growth as described in Methods.

\begin{tabular}{|c|c|c|c|c|c|}
\hline $\begin{array}{l}\text { Inoculum growth } \\
\text { temperature } \\
\left({ }^{\circ} \mathrm{C}\right)\end{array}$ & $\begin{array}{l}\text { Temperature } \\
\text { of growth } \\
\text { reinitiation } \\
\left({ }^{\circ} \mathrm{C}\right)\end{array}$ & $\begin{array}{l}\text { Time after } \\
\text { reinitiation } \\
\text { of growth } \\
\text { (min) }\end{array}$ & $\begin{array}{c}\text { Cells } \\
\text { counted }\end{array}$ & $\begin{array}{l}\text { Cells } \\
\text { with } \geqslant 2 \\
\text { division } \\
\text { cycles }\end{array}$ & $\begin{array}{l}\text { Buds emerging } \\
\text { adjacent to } \\
\text { scar* } \\
(\%)\end{array}$ \\
\hline 28 & 28 & $\begin{array}{l}205 \\
250\end{array}$ & $\begin{array}{l}122 \dagger \\
163\end{array}$ & $\begin{array}{l}59 \\
83\end{array}$ & $\begin{array}{l}64 \\
87\end{array}$ \\
\hline 28 & 37 & $\begin{array}{l}160 \\
220 \\
295 \\
480 \\
515\end{array}$ & $\begin{array}{l}523 \ddagger \\
337 \\
513 \\
363 \\
433\end{array}$ & $\begin{array}{l}43 \\
37 \\
42 \\
36 \\
48\end{array}$ & $\begin{array}{l}30 \\
54 \\
90 \\
39 \\
38\end{array}$ \\
\hline 37 & 28 & $\begin{array}{l}180 \\
315\end{array}$ & $\begin{array}{l}156 \dagger \\
101\end{array}$ & $\begin{array}{l}69 \\
45\end{array}$ & $\begin{array}{l}25 \\
98\end{array}$ \\
\hline 37 & 37 & $\begin{array}{l}180 \\
255 \\
355\end{array}$ & $\begin{array}{l}457 \ddagger \\
528 \\
265\end{array}$ & $\begin{array}{l}33 \\
36 \\
25\end{array}$ & $\begin{array}{l}18 \\
47 \\
52\end{array}$ \\
\hline
\end{tabular}

\footnotetext{
- The location of the emerging bud was tabulated as adjacent or non-adjacent to a previous scar irrespective of the scar distribution of the cell. Only cells with buds less than one half the diameter of the parent cell were included in the determinations.

† Only cells with buds less than one half the diameter of the parent cell were counted.

$\ddagger$ All cells were counted.
}

temperature, approximately $60 \%$ of the buds on scarred cells emerged adjacent to a scar, whereas when growth was reinitiated at the higher temperature, about $50 \%$ of the buds in scarred cells emerged adjacent to a scar. Similar patterns were observed when yeast grown at $37^{\circ} \mathrm{C}$ resumed yeast growth at $28^{\circ} \mathrm{C}$ or $37^{\circ} \mathrm{C}$. The distributions were thus not characteristic of either growth condition and were more variable than previously determined.

Because the bud scar pattern did not reflect the conditions of culture used to induce resumption of growth, experiments to investigate the second possibility, which would reflect a transition between modes, were carried out. The budding pattern was observed at intervals after resuspension of cells in fresh medium (Table 4). The budding pattern changed between intervals. In cultures resuming growth at $28^{\circ} \mathrm{C}$, the percentage of buds emerging adjacent to a bud scar increased during the transition to a distribution similar to that observed in cultures growing at $28^{\circ} \mathrm{C}$. Cells resuming growth at $37^{\circ} \mathrm{C}$ also were observed to change the distribution frequency toward adjacent sites, although yeasts in growing cultures under the same conditions showed a pattern of non-adjacent budding (Table 1). In order to display the non-adjacent budding pattern observed in cultures growing at $37^{\circ} \mathrm{C}$, cells would have to reverse this pattern. This reversal was observed in cells grown at $28^{\circ} \mathrm{C}$ and resuspended at $37^{\circ} \mathrm{C}$ (Table 4). At the later observation times the non-adjacent pattern was predominant.

Yeast cells grown to stationary phase at $25^{\circ} \mathrm{C}$ will form germ tubes when resuspended and diluted in fresh medium ( $\mathrm{pH} \mathrm{7.4)}$ ) at $37^{\circ} \mathrm{C}$. By four hours, more than $90 \%$ of the cells form germ tubes. The orientation of germ tube emergence with respect to the bud scar(s) from yeast growth was examined. The fluorescent scar(s) present on the stationary phase cells persisted during the period of germ tube formation. Ninety-five percent of the germ tubes emerged at sites which were not adjacent to previous budding sites (Table 2). The frequency was the same if site selection was observed early or late during conversion. Germ tube formation was initiated in positions that were lateral (Fig. $1 \mathrm{~g}$ ) or opposite (Fig. $1 \mathrm{f}$ ) to bud scars. The site selection of germ tube emergence was significantly different from the budding pattern at $28^{\circ} \mathrm{C}$. In addition, the frequency of non-adjacent germ tube emergence was greater than the frequency of non-adjacent budding at $37^{\circ} \mathrm{C}$. Since yeasts grown at $37^{\circ} \mathrm{C}$ did not consistently form high numbers of germ tubes, the site selection for germ tube emergence was not determined for cells with non-adjacent budding histories. 


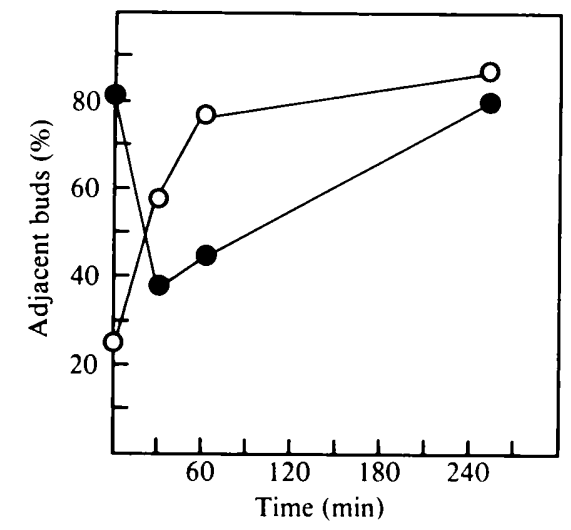

Fig. 2. Site selection for buds following temperature shift. Cells growing at $28^{\circ} \mathrm{C}, \mathrm{pH} 7 \cdot 4$, or $37^{\circ} \mathrm{C}$, pH 4.5, were shifted to the other condition and the pattern of emerging buds was determined at intervals following the shift. Only cells with buds less than one half the diameter of the parent cell and with at least one scar were included in the determination of site selection. Cells shifted from $28^{\circ} \mathrm{C}$, $\mathrm{pH} 7.4$ to $37^{\circ} \mathrm{C}$, pH 4.5 ; O, cells shifted from $37^{\circ} \mathrm{C}, \mathrm{pH} 4.5$ to $28^{\circ} \mathrm{C}, \mathrm{pH} 7.4$.

\section{Bud site selection following temperature shift}

The initial response of cells with an established pattern of bud site selection to conditions favouring a different pattern was observed. Cultures growing at $28^{\circ} \mathrm{C}, \mathrm{pH} 7.4$ were shifted to $37^{\circ} \mathrm{C}, \mathrm{pH} 4.5$ and vice versa. The site selection of emerging buds was determined following the shift (Fig. 2). The frequency of budded cells initially decreased then increased in each shifted culture (data not shown). Cells in cultures shifted to $28^{\circ} \mathrm{C}$ showed a progressive increase in the frequency of buds emerging in adjacent positions. This simple transition between budding patterns was not observed in cultures shifted to $37^{\circ} \mathrm{C}$. Initially, the frequency of adjacent site selection decreased and non-adjacent site selection characteristic of the new conditions increased. However, this change was transitory and the frequency of adjacent site selection returned to preshift frequencies. Examination of the budding pattern on cells in stationary phase from a shifted culture showed the non-adjacent budding pattern. Consequently, the budding pattern was changed to the non-adjacent mode, characteristic of growth at $37^{\circ} \mathrm{C}$.

\section{DISCUSSION}

Site selection for bud emergence is an event in cellular morphogenesis which occurs with each yeast cell division cycle, whereas site selection for germ tube formation is one event in morphological morphogenesis which occurs once for each hyphal element. While the identity(s) of the functional entity(s) controlling site selection is not known, several of its characteristics can be demonstrated or deduced.

During asexual growth, most of the enlargement is restricted to the bud or to the germ tube and elongating hypha. Consequently, one aspect of site selection is that it activates and limits cell wall biosynthesis to specific locations.

In the range $23-28^{\circ} \mathrm{C}$, the budding site selector in C. albicans distinguished the poles or ends of the long axis of the ellipsoidal shaped yeasts. Time-lapse photomicroscopy and bud scar histories demonstrated that the ends of the cells usually served as sites for bud formation (Table 1, Fig. 1). In most cells growing at these temperatures, consecutive site selections occurred at the same end of the cell and adjacent to each other. These observations suggested that some memory or element of the budding site selector persisted between cell divisions, remained in place throughout the cell cycle and identified the pole of bud formation. Since some cells showed evidence of budding at both ends, such memory was not immutably fixed at one end.However, even in these cells memory persisted through several cell division cycles (Table 2). In cells 
growing on solid medium, new daughter cells were able to distinguish the birth end of the cell. First buds emerged at the birth end in $70 \%$ of the cells observed.

Stationary phase cells accumulate in an unbudded, presumably $\mathrm{Gl}$ cell cycle stage (Chaffin \& Sogin, 1976; Wain et al., 1976; Soll \& Bedell, 1978). Cells emerging from stationary phase did not show the same specificity of bud site selection as in the previous growth state (Tables 1 and 3). Consequently, the site selector did not persist once active cell division ceased and apparently had to be re-established when growth was resumed.

Some characteristics of the site selector in cells growing at $37^{\circ} \mathrm{C}$ appeared to be different. At $37^{\circ} \mathrm{C}$ bud scars were observed at both ends of the long axis as well as along the short axis (Table 1, Fig. 1). From the observations in this report it was not possible to distinguish between specific non-adjacent and random site selection. As was observed for the site selector at lower temperatures, the site selector at $37^{\circ} \mathrm{C}$ was lost when cells entered a nonproliferative resting state in stationary phase. When cells resumed growth, the initial budding pattern was not associated with either mode of site selection (Tables 3 and 4).

Actively dividing cells with one site selector were able to switch to the alternative pattern (Fig. 2). Cells shifted down from $37^{\circ} \mathrm{C}$ to $28^{\circ} \mathrm{C}$ rapidly acquired the pattern of adjacent, polar budding. However, cells shifted up, did not respond in the same way. A rapid, transitory shift to the non-adjacent pattern was observed which was followed by a return to the adjacent pattern. Ultimately, the non-adjacent pattern was acquired as indicated by the budding history of stationary phase cells. A comparison of the frequencies of adjacent budding for cells grown at $28^{\circ} \mathrm{C}$ at pH 7.4 and 4.5 with the frequency of adjacent budding for cells grown at $37^{\circ} \mathrm{C}$ at $\mathrm{pH} 4.5$ suggested that growth temperatare was an important factor in determining the pattern observed.

Studies with other yeasts suggest that both modes of site selection should be considered active processes. That is, non-adjacent site selection is not the result of a non-functional site selection process or vice versa. Temperature-sensitive mutants of $S$. cerevisiae defective in the CDC24 gene and Mc mutants of Wangiella dermatitidis which appear to have lost site selection have some common phenotypic properties (Sloat et al., 1981; Szaniszlo et al., 1976; Roberts \& Szaniszlo, 1978, 1980; Roberts et al., 1979; Jacobs, 1983). These include inhibition of budding, delocalization of some cell wall polysaccharides and spherical growth. Consequently, the loss of the site selection function might be expected to result in loss of budding and formation of large cells. A change in the budding pattern with growth conditions has been observed in other yeasts. In $W$. dermatitidis, the frequency of budding at the same site is increased at $37^{\circ} \mathrm{C}$ compared to the frequency observed at $25^{\circ} \mathrm{C}$ (C. W. Jacobs \& P. J. Szaniszlo, personal communication). When $S$. cerevisiae, is grown in chemostat cultures, the percentage of cells with scars at the same pole decreased as the doubling time increased (Thompson $\&$ Wheals, 1980). Over the range of doubling times (110-150 min) observed for $C$. albicans under the conditions used in this study, the decrease reported for $S$. cerevisiae is approximately $5 \%$.

Any model for the relationship between the budding patterns observed must consider the following observations. (1) Two modes of site selection were observed, each characteristic of the culture growth condition. (2) Cells for which the conditions of cultivation to stationary phase and growth resumption were the same and which had not been incubated under the second condition, transitorily displayed an uncharacteristic mode of site selection. (3) Each mode could be expressed under non-characteristic conditions several hours after transfer. These observations eliminate simple condition-specific expression and function and rapid inactivation of function under non-characteristic conditions as reasonable hypotheses. Several models, including features of constitutive or sequential synthesis of site selection factor(s), selective synthesis or inhibition, can be formulated. Among these, one of the more simple is the following: when presented with a stimulus to bud (e.g. fresh medium, new conditions), cells are programmed to go through non-adjacent and adjacent budding modes before establishing the characteristic pattern. Such a model could be modified by proposing that the adjacent mode is dominant to the non-adjacent and, after programmed synthesis, continued expression is dependent on conditions. 
When cells of $C$. albicans are recovered following subcutaneous inoculation into mice, germ tubes are observed to emerge at any surface location (Mackenzie, 1964). In this report, germ tubes were observed to emerge along both the short and long axes of cells. The sites selected for germ tube formation were not adjacent to previous sites of bud emergence (Table 3). Although non-adjacent site selection was observed for both bud and germ tube emergence at $37^{\circ} \mathrm{C}$, three observations suggest that the site selectors for buds and germ tubes might not be the same. First, that aspect of site selection which activates cell wall biosynthesis is not identical. Hyphae grow by apical extension rather than by a combination of apical and spherical growth for buds (Farkaš, 1979) and there is a quantitative difference in cell wall constituents, particularly chitin (Chattaway et al., 1968). In addition, a filament ring forms at the selected site in bud formation and distal to the selected site along the hypha in germ tube formation (Soll \& Mitchell, 1983). Although a temporal model has been proposed for the difference, this observation suggests that the interaction of the site selector and other localized phenomena differ in the two morphologies. Two differences in the non-adjacent site selection for buds and germ tubes were observed in this report. The frequency of non-adjacent site selection for germ tubes was higher than for buds. No sequential transition from non-adjacent to adjacent to non-adjacent site selection was observed. The frequency of non-adjacent site selection was the same throughout germination, unlike the changing pattern observed during initiation of budding growth.

C. W. Jacobs and P. J. Szaniszlo are thanked for helpful discussions, and P. J. Szaniszlo and D. C. Straus are thanked for reading the manuscript.

\section{REFERENCES}

Beran, K. (1968). Budding of yeast cells, their scars and ageing. Advances in Microbial Physiology 2, 143171.

Cassone, A., Simonetti, N. \& Strippoli, V. (1973). Ultrastructural changes in the wall during germ-tube formation from blastospores of Candida albicans. Journal of General Microbiology 77, 417-426.

Chaffin, W. L. \& Sogin, S. J. (1976). Germ tube formation from zonal rotor fractions of Candida albicans. Journal of Bacteriology 126, 771-776.

Chattaway, F. W., Holmes, M. R. \& Barlow, A. J. E. (1968). Cell wall composition of the mycelial and blastospore forms of Candida albicans. Journal of General Microbiology 51, 367-376.

Chattaway, F. W., Bishop, R., Holmes, M. R. \& ODDs, F. C. (1973). Enzyme activities associated with carbohydrate synthesis and breakdown in the yeast and mycelial forms of Candida albicans. Journal of General Microbiology 75, 97-109.

FARKAS̆, V. (1979). Biosynthesis of cell walls of fungi. Microbiological Reviews 43, 117-144.

HARTWELl, L. H. \& UNGeR, M. W. (1977). Unequal division in Saccharomyces cerevisiae and its implications for the control of cell division. Journal of Cell Biology 75, 422-435.

Hayashibe, M. \& Katohda, S. (1973). Initiation of budding and chitin ring. Journal of General and Applied Microbiology 19, 23-39.

JACOBS, C. W. (1983). Events associated with cellular development and differentiation in Wangiella dermatitidis. Ph.D thesis, University of Texas at Austin, USA.

LeE, K. L., Buckley, H. R. \& CAMpbell, C. C. (1975). An amino acid liquid synthetic medium for development of mycelial and yeast forms of Candida albicans. Sabouraudia 13, 148-153.
Mackenzie, D. W. R. (1964). Morphogenesis of Candida albicans in vivo. Sabouraudia 3, 225-232.

MAeDA, H. \& IsHIDA, N. (1967). Specificity of binding hexopyranosyl polysaccharides with fluorescent brightener. Journal of Biochemistry 62, 276-278.

Mrtchell, L. H. \& SolL, D. R. (1979a). Commitment to germ tube or bud formation during release from stationary phase in Candida albicans. Experimental Cell Research 120, 167-179.

Mitchell, L. \& Soll, D. R. (1979b). Temporal and spatial differences in septation during synchronous mycelium and bud formation in Candida albicans. Experimental Mycology 3, 298-309.

NiCKERSON, W. J. (1963). Symposium on biochemical bases of morphogenesis in fungi. IV. Molecular bases of form in yeasts. Bacteriological Reviews 27, 305-324.

Roberts, R. L. \& Szaniszlo, P. J. (1978). Temperature-sensitive multicellular mutants of Wangiella dermatitidis. Journal of Bacteriology 135, 622-632.

RoberTs, R. L. \& Szaniszlo, P. J. (1980). Yeast-phase cell cycle of the polymorphic fungus Wangiella dermatitidis. Journal of Bacteriology 144, 721-731.

Roberts, R. L., Lo, R. J. \& Szaniszlo, P. J. (1979). Nuclear division in temperature-sensitive multicellular mutants of Wangiella dermatitidis. Journal of Bacteriology 137, 1456-1458.

Sloat, B. F., Adams, A. \& Pringle, J. R. (1981). Roles of the CDC24 gene product in cellular morphogenesis during the Saccharomyces cerevisiae cell cycle. Journal of Cell Biology 89, 395-405.

Soll, D. R. \& Bedell, G. W. (1978). Bud formation and the inducibility of pseudo-mycelium outgrowth during release from stationary phase in Candida albicans. Journal of General Microbiology 108, 173180. 
Soll, D. R. \& MrTCHELL, L. H. (1983). Filament ring formation in the dimorphic yeast Candida albicans. Journal of Cell Biology 96, 486-493.

Szaniszlo, P. J., Hseih, P. H. \& Marlowe, J. D. (1976). Induction and ultrastructure of the multicellular (sclerotic) morphology in Phialophora dermatitidis. Mycologia 68, 117-130.

Thompson, P. W. \& Wheals, A. E. (1980). Asymmetri- cal division of Saccharomyces cerevisiae in glucoselimited chemostat culture. Journal of General Microbiology 121, 401-409.

Wain, W. H., Price, M. F., Brayton, A. R. \& CAwson, R. A. (1976). Macromolecular synthesis during the cell cycles of the yeast and hyphal phases of Candida albicans. Journal of General Microbiology 97, 211-217. 